Kebijakan: Jurnal Ilmu Administrasi

Volume 11, Nomor 1, Januari 2020

E-ISSN: 2656-2820

P-ISSN 1829-5762

\title{
PENGARUH KUALITAS PELAYANAN E-KTP TERHADAP KEPUASAN MASYARAKAT DI KECAMATAN KRAMATMULYA
}

\author{
Ahtu Duriat ${ }^{1 *}$, Regan Vaughan ${ }^{2)}$ \\ ${ }^{1)}$ Prodi Administrasi Publik, FISIP, Universitas Pasundan \\ Bandung, Jawa Barat, Indonesia \\ ahtu.duriat@unpas.ac.id \\ ${ }^{2}$ Prodi Administrasi Publik, FISIP, Universitas Pasundan \\ Bandung, Jawa Barat, Indonesia \\ reganvaughan88@gmail.com
}

\begin{abstract}
ABSTRAK
Penelitian ini berjudul "Pengaruh Kualitas Pelayanan E-KTP Terhadap Kepuasan Masyarakat Kecamatan Kramatmulya Kabupaten Kuningan”. Pemerintah merupakan organisasi birokrasi dalam pelayanan publik, maka organisasi birokrasi pemerintahan merupakan organisasi terdepan yang berhubungan dengan pelayanan publik. Untuk mewujudkan pelayanan publik yang baik, maka pemerintah harus menempatkan jumlah dan kualitas staf/aparat yang ada sesuai dan memiliki pemahaman akan pelayanan publik yang baik. Pelayanan publik di Kecamatan Kramatmulya, Kabupaten Kuningan khusunya pelayanan pengurusan e-KTP dirasakan masih berbelit-belit, adanya ketidaktepatan waktu pelayanan, serta keramahan aparat pemerintah dalam pemberian pelayanan dinilai masih kurang. Hal inilah yang kemudian menjadi dasar adanya penelitian ini. Tujuan Penelitian ini adalah untuk mengetahui dan menganalisis besarnya pengaruh Kualitas Pelayanan e-KTP terhadap Kepuasan Masyarakat di Kecamatan Kramatmulya. Metode penelitian yang digunakan adalah metode penelitian deskriptif survei dengan menggunakan analisis kuantitatif. Berdasarkan hasil penelitian diketahui pengaruh kualitas pelayanan e-ktp di Kecamatan Kramatmulya Kabupaten Kuningan yang diukur melalui dimensi pelayanan yakni Bukti Langsung (Tangibles), Kehandalan (Reliability), Daya Tanggap (Responsiveness), Jaminan (Assurance), Empati (Emphaty) sebesar 70,6 \% (tujuh puluh koma enam persen), hal ini membuktikan bahwa kualitas pelayanan e-ktp mempunyai pengaruh terhadap kepuasan masyarakat.
\end{abstract}

Kata Kunci: Kualitas Pelayanan, Kepuasan Masyarakat.

\begin{abstract}
This study entitled "The Effect of E-KTP Service Quality on Community Satisfaction in Kramatmulya District, Kuningan Regency". The government is a bureaucratic organization in public services, so the government bureaucratic organization is the foremost organization that deals with public services. To realize good public services, the government must place the number and quality of existing staff / apparatus accordingly and have an understanding of good public services. Public services in Kramatmulya Subdistrict, Kuningan Regency, especially e-KTP management services, are still felt to be convoluted, there is an inaccuracy in service time, and the friendliness of government officials in providing services is considered to be still lacking. This then becomes the basis for this research. The purpose of this study was to determine and analyze the magnitude of the influence of e-KTP Service Quality on Community Satisfaction in Kramatmulya District. The research method used is a descriptive survey research method using quantitative analysis. Based on the research results, it is known that the effect of the e-ID card service quality in Kramatmulya District, Kuningan Regency is measured through the service dimensions, namely Direct Evidence (Tangibles), Reliability (Reliability), Responsiveness (Responsiveness), Guarantee (Assurance), Empathy (Emphaty) of 70, 6\% (seventy point six percent), this proves that the quality of e-KTP service has an influence on community satisfaction.
\end{abstract}

Keywords: Service Quality, Community Satisfaction. 


\section{Kebijakan: Jurnal Ilmu Administrasi \\ Volume 11, Nomor 1, Januari 2020 \\ E-ISSN: 2656-2820 \\ P-ISSN 1829-5762}

\section{PENDAHULUAN}

Organisasi adalah sebuah wadah atau tempat berkumpulnya sekelompok orang untuk bekerjasama secara rasional dan sistematis, terkendali dan terpimpin untuk mencapai suatu tujuan tertentu dengan memanfaatkan sumber daya yang ada. Pada umumnya organisasi akan memanfaatkan berbagai sumber daya tertentu dalam rangka untuk mencapai tujuan, seperti; uang, mesin, metode/cara, lingkungan, sumber daya manusia dan sumber daya lainnya, yang dilakukan secara sistematis, rasional dan terkendali. Jika pemerintah merupakan organisasi birokrasi dalam pelayanan publik, maka organisasi birokrasi pemerintahan merupakan organisasi terdepan yang berhubungan dengan pelayanan publik. Pelayanan masyarakat menuntut setiap unsur di dalam lembaga tersebut untuk memberikan pelayanan prima kepada masyarakat. Pelayan prima sendiri mengandung arti sebagai salah satu usaha yang dilakukan pemerintah untuk melayani masyarakat sebaik-baiknya, sehingga dapat memberikan kepuasan kepada masyarakat dan memenuhi kebutuhan serta keinginan masyarakat.

Menurut undang-undang no 25 tahun 2009 tentang pelayanan publik, sebagaimana yang tertera pada bab 1 ketentuan umum pasal 1 bahwa pelayanan publik adalah kegiatan atau rangkaian kegiatan dalam rangka pemenuhan kebutuhan pelayanan sesuai dengan peraturan perundang-undangan bagi setiap warga negara dan penduduk atas barang, jasa, dan/atau pelayanan administratif yang diselenggarakan oleh penyelenggara pelayanan publik. Pelayanan publik yang baik tentunya memiliki standar kualitas yang harus dipenuhi. Untuk mewujudkan pelayanan publik yang baik, maka pemerintah harus menempatkan jumlah dan kualitas staf/aparat yang ada sesuai dan memiliki pemahaman akan pelayanan publik yang baik. Dengan demikian, pelayan publik yang baik dan tepat sasaran akan mendekatkan birokrasi dengān masyarakat. Melayani masyarakat dengan baik adalah merupakan tanggung jawab bagi semua instansi pemerintah. Dengan demikian, maka setiap pegawai dalam instansi pemerintah harus melayani masyarakat dan mempelajari cara meningkatkan keterampilan untuk melayani. Di dalam keterampilan melayani, termasuk pula di dalamnya adalah penguasaan terhadap pengetahuan jasa layanan yang diberikan, karena hal ini akan menunjukkan kepada masyarakat bahwa pegawai dalam instansi pemerintah tersebut adalah seorang profesional di bidang Manajemen Pelayanan Publik. Kecamatan adalah salah satu unsur pelayanan publik di daerah dan salah satu bentuk pelayanan yang diberikan adalah pelayanan administrasi kependudukan. Untuk Kecamatan Kramatmulya sendiri, pelaksanaan administrasi kependudukan bagi masyarakat dilaksanakan di kantor Kecamatan Kramatmulya. Agar pelayanan pengurusan administrasi kependudukan yang diberikan aparatur Kecamatan Kramatmulya ini dapat terlaksana dengan baik, maka diperlukan sarana dan prasarana yang baik, seperti prosedur dan koordinasi kerja yang. Selain itu harus ditunjang pula oleh sumber daya manusia yang memiliki kemampuan kerja tinggi untuk melaksanakan hal tersebut, baik itu ketersediaan pegawai, peralatan kerja, komunikasi kerja, keterampilan pegawai dalam pelaksanaan kerja maupun pengetahuan pegawai terhadap pekerjaan yang dilakukan.

Argumen dasar dari penelitian ini adalah bahwa untuk bisa menilai kualitas pelayanan publik, diperlukan suatu pemahaman yang bisa membantu memahami bagaimana seharusnya lembaga pelayanan publik ini bekerja sehingga bisa menghasilakan output yang berkualitas. Output yang berkualitas disini mencakup output yang bagus dan sesuai dengan tingkat kepuasan masyarakat. Pelayanan pembuatan e-KTP merupakan salah satu contoh bentuk pelayanan publik yang diberikan oleh aparatur pemerintah. Proyek e-KTP ini dilatarbelakangi oleh sistem pembuatan KTP konvensional di Indonesia yang memungkinkan seseorang dapat memiliki lebih dari satu KTP. Hal ini disebabkan belum adanya basis data terpadu yang menghimpun data penduduk dari seluruh Indonesia. 


\section{Kebijakan: Jurnal Ilmu Administrasi Volume 11, Nomor 1, Januari 2020 E-ISSN: 2656-2820 P-ISSN 1829-5762}

Fakta tersebut memberi peluang penduduk yang ingin berbuat curang terhadap negara dengan menduplikasi KTP-nya. Salah satu kasus dalam pembuatan e-KTP adalah kekecewaan masyarakat terhadap keterlambatan pencetakan e-KTP yang seharusnya waktu menunggu adalah sekurangkurangnya satu minggu, namun dalam pelaksanaannya tidak sedikit masyarakat yang harus menunggu hingga 3 sampai 5 bulan bahkan 1 tahun untuk mendapatkan e-KTP yang baru. Hal ini dikarenakan adanya keterlambatan distribusi belangko e-KTP dari kantor pusat. Berdasarkan survey awal penelitian di lapangan pada masyarakat Kecamatan Kramatmulya, diketahui bahwa pengurusan e-KTP dirasakan masih berbelit-belit, adanya ketidaktepatan waktu pelayanan, serta keramahan aparat pemerintah dalam pemberian pelayanan dinilai masih kurang. Hal-hal seperti inilah yang menjadi dasar tuntutan agar terjadi perubahan dalam aparatur pemerintah, khususnya menyangkut pelayanan publik yang diberikan kepada masyarakat. Rendahnya mutu pelayanan publik memberikan citra buruk pemerintah di mata masyarakat. Pelayanan publik dapat dikategorikan efektif apabila masyarakat mendapatkan kemudahan pelayanan dengan prosedur yang singkat, cepat, tepat dan memuaskan. Keberhasilan meningkatkan efektivitas pelayanan umum ditentukan oleh faktor kemampuan pemerintah dalam meningkatkan disiplin kerja aparat pelayanan. Khususnya di pemerintahan Kecamatan Kramatmulya, Kabupaten Kuningan dituntut untuk mewujudkan disiplin kerja yang lebih baik untuk meningkatkan kualitas pelayanan. Berdasarkan kondisi yang ditemukan di lapangan, maka peneliti tertarik untuk melakukan penelitian tentang Pengaruh Kualitas Pelayanan e-KTP Terhadap Kepuasan Masyarakat.

Zeithaml (dalam Hardiansyah, 2011:40) memberikan pengertian tentang kualitas pelayanan, yakni "Kualitas pelayanan merupakan suatu metode yang diturunkan secara empiris yang dapat digunakan oleh organisasi pelayanan untuk meningkatkan kualitas pelayanan. Metode ini meliputi pengembangan pemahaman mengenai kebutuhan layanan yang dirasakan oleh pelanggan". Berdasarkan pengertian di atas, maka diketahui kualitas pelayanan publik adalah totalitas dari kemampuan pihak penyelenggara pelayanan dalam memberikan layanan akan produk (barang atau jasa) maupun layanan administrasi kepada pelanggan atau masyarakat, yang dapat memenuhi kebutuhan dan dapat memberikan kepuasan kepada pelanggan berdasarkan kesesuaian dengan harapan dan kenyataan yang diterima oleh pelanggan atau masyarakat. Selanjutnya Priansa (2012:156) mengatakan bahwa "Kepuasan publik merupakan respons publik terhadap ketidaksesuaian antara tingkat harapan yang dimiliki dan kinerja aktual yang dirasakan setelah memanfaatkan pelayanan publik". Berdasarkan pengertian di atas, diketuahi bahwa kepuasan publik adalah perasaan senang atau kecewa yang dirasakan oleh publik berdasarkan perbandingan antara kenyataan yang diperoleh dan harapan yang dimiliki oleh publik.

\section{METODE}

Obyek penelitian yang dilakukan oleh peneliti berada di Kecamatan Kramatmulya Kabupaten Kuningan. Penelitian dimulai dari tanggal 28 Juli sampai dengan 7Agustus 2019. Metode penelitian yang digunakan oleh peneliti adalah metode penelitian deskriptif survei dengan menggunakan analisis kuantitatif. Menurut Nawawi dalam Satibi (2011:76) Deskriptif survey merupakan metode penelitian yang bertujuan untuk menemukan deskripso general dan universal, yang berlaku pada sejumlah variasi situasi dan kondisi. Populasi dan sampel dari penelitian ini adalah unit observasi yang terdapat pada masyarakat di Kecamatan Kramatmulya Kabupaten Kuningan dengan anggota populasi sekurang-kurangnya sebanyak 30 orang yang ditentukan dengan teknik accidental sampling dalam penentuan samplingnya. Accidental sampling merupakan teknik pengumpulan sampel berdasarkan kebetulan yaitu siapa saja yang secara kebetulan bertemu dengan peneliti dapat digunakan sebagai 


\section{Kebijakan: Jurnal Ilmu Administrasi \\ Volume 11, Nomor 1, Januari 2020 \\ E-ISSN: 2656-2820 \\ P-ISSN 1829-5762}

sampel apabila orang tersebut dirasa cocok untuk dijadikan sumber data dalam hal ini adalah masyarakat yang sedang melakukan pelayanan di kecamatan Kramatmulya. Teknik analisis data merupakan teknik yang memudahkan dan mendukung dalam mengolah data yang diperoleh dari wawancara dan angket. Untuk memenuhi syarat valid dan relibel atas hasil yang diteliti maka dibutuhkan cara untuk mengukur validitas dan realibilitas.

1. Validitas dalam penelitian menyatakan derajat ketepatan alat ukur penelitian terhadap isi sebenarnya yang diukur. Ghozali (2009) menyatakan bahwa validitas digunakan untuk mengukur sah atau valid tidaknya suatu kuisioner. Teknik yang biasanya digunakan dalam uji validitas adalah menggunakan Person Product Moment. Apabila skor korelasi (r) $\geq 0,3$ maka item tersebut valid.

$$
r_{\text {hitung }}=\frac{n\left(\sum X_{i} Y_{i}\right)-\left(\sum X_{i}\right) \cdot\left(Y_{i}\right)}{\left.\sqrt{\left\{n \cdot \sum X_{i}^{2}\right.}-\left(\sum X_{i}\right)^{2}\right\} \cdot\left\{n \cdot \sum Y_{i}^{2}-\left(\sum Y_{i}\right)^{2}\right\}}
$$

Dimana :

$r_{\text {hitung }}=$ Koefisien relasi

$\sum \mathrm{X}_{\mathrm{i}} \quad=$ Jumlah skor item

$\sum \mathrm{Y}_{\mathrm{i}} \quad=$ Jumlah skor total (seluruh item)

$n \quad=$ Jumlah responden

2. Uji Reliabilitas bertujuan untuk menunjukan sejauh mana suatu hasil pengukuran relatif konsisten apabila pengukuran diulangi dua kali atau lebih. Jadi dengan kata lain bahwa Reliabilitas adalah indeks yang menunjukan sejauh mana suatu alat pengukur dapat dipercaya atau dapat diandalkan, bila alat pengukur tersebut digunakan dua kali atau lebih, untuk mengukur gejala yang sama dan hasil pengukuran yang diperoleh relatif konsisten. Teknik pengujian reliabilitas yang digunakan dalam penelitian ini yaitu uji reliabilitas dengan menggunakan teknik Cronbach Alpha, yaitu menghitung koefesien Alpha yang merupakan rata-rata dari koefesien belah dua yang dihitung untuk semua kemungkinan membelah dua item-item score, perumusannya adalah sebagai berikut :

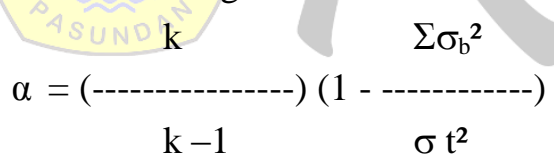

Dimana :

$\alpha=$ Reliablitas Instrument

$\mathrm{k}=$ Banyak butir pertanyaan

$\sigma \mathrm{t}^{2} \quad=$ Varians Total

$\Sigma \sigma_{\mathrm{b}}^{2} \quad=$ Jumlah Varians Butir

3. Teknik analisis yang digunakan oleh peneliti adalah regresi linier sederhana. Sugiyono (2014:270) mengemukakan bahwa teknik analisis data regresi linier sederhana adalah didasarkan pada hubungan fungsional ataupun kausal satu variabel independen dengan satu variabel dependen.

Berikut persamaan umum regresi linier sederhana :

$Y^{\prime}=a+b X$

Dimana :

$Y^{\prime}$ :subyek/nilai dalam variabel dependen diprediksikan

$a$ : Harga $\mathrm{Y}$ bila $\mathrm{X}=0$ (harga konstan)

$b$ : Angka arah atau koefisien regresi, yang menunjukan angka peningkatan ataupun penurunan variabel dependen yang didasarkan pada variabel independen. Bila b (+) maka naik, dan bila (-) maka terjadi penurunan.

$X$ : Subyek variabel independen yang memiliki nilai tertentu. 
Kebijakan: Jurnal Ilmu Administrasi

Volume 11, Nomor 1, Januari 2020

E-ISSN: 2656-2820

P-ISSN 1829-5762

Tabel 3.1 : Kriteria Penilaian Berdasarkan Persentase

\begin{tabular}{|l|l|l|}
\hline No & Persentase & Kriteria Penilaian \\
\hline 1 & $20,00-35,99$ & Tidak Baik \\
\hline 2 & $36,00-51,99$ & Kurang Baik \\
\hline 3 & $52,00-67,99$ & Cukup Baik \\
\hline 4 & $68,00-83,99$ & Baik \\
\hline 5 & $84,00-100,00$ & Sangat Baik \\
\hline
\end{tabular}

\section{HASIL PENELITIAN DAN PEMBAHASAN}

A. Hasil Penelitian

1) Hasil Uji Validitas Kuisioner Variabel $X($ KualitasPelayanan)

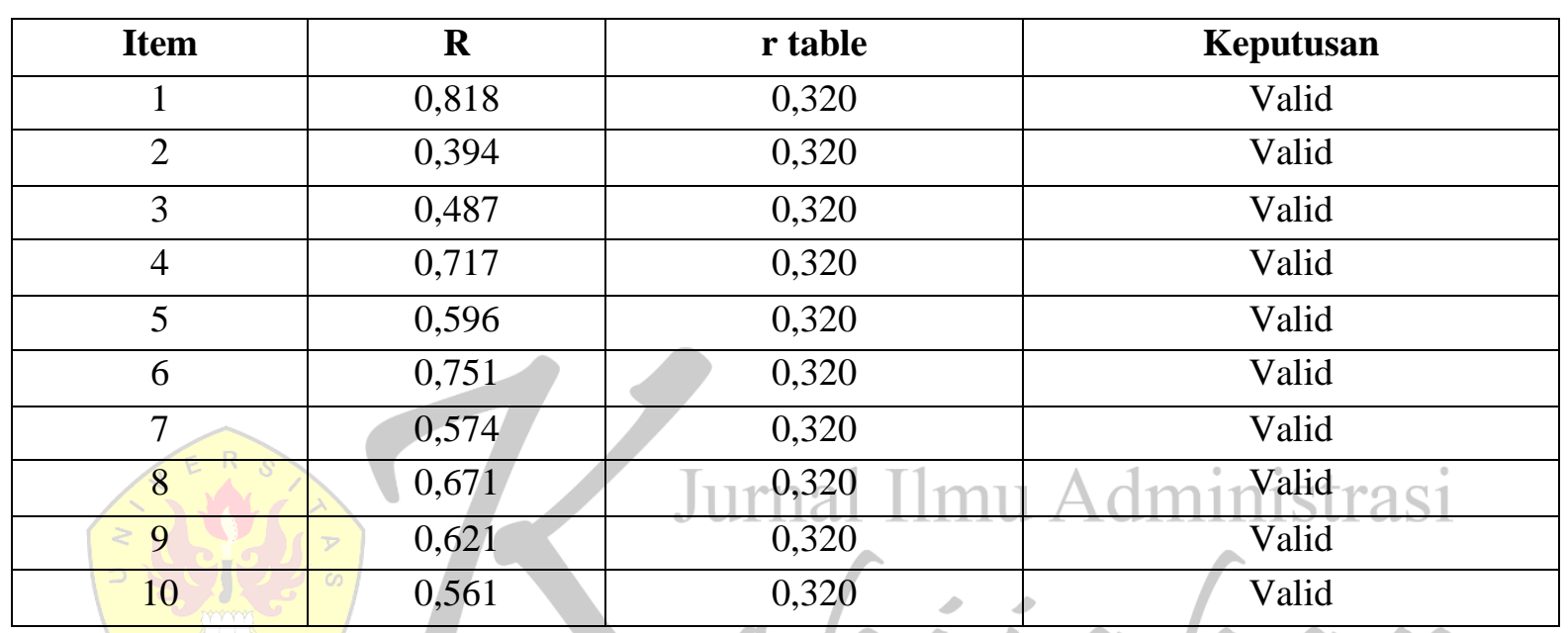

Berdasarkan tabel tersebut dapat diketahui bahwa 10 item yang diuji $\left(\mathrm{r}_{\text {hitung }}\right)$ menunjukan angka lebih besar dari koefisien korelasi Product Moment $\left(\mathrm{r}_{\text {tabel }}\right)$. Jadi peneliti menyimpulkan bahwa 10 item variabel $\mathrm{X}$ valid dan dapat dipergunakan untuk pengumpulan data.

2) Hasil Uji Validitas Variabel Y (Kepuasan Masyarakat).

\begin{tabular}{|c|c|c|c|}
\hline Item & $\mathbf{R}$ & r table & Keputusan \\
\hline 11 & 0,841 & 0,320 & Valid \\
\hline 12 & 0,709 & 0,320 & Valid \\
\hline 13 & 0,701 & 0,320 & Valid \\
\hline 14 & 0,802 & 0,320 & Valid \\
\hline 15 & 0,694 & 0,320 & Valid \\
\hline 16 & 0,841 & 0,320 & Valid \\
\hline
\end{tabular}

Berdasarkan tabel tersebut dapat diketahui bahwa 6 item yang diuji $\left(\mathrm{r}_{\text {hitung }}\right)$ menunjukan angka yang lebih besar dari koefisien korelasi Product Moment $\left(\mathrm{r}_{\text {tabel }}\right)$. Jadi peneliti menyimpulkan bahwa 6 item variabel $\mathrm{Y}$ valid dan dapat dipergunakan untuk pengumpulan data. 
3) Hasil Uji Reliability Variabel X

\begin{tabular}{|c|c|c|}
\hline Cronbach's Alpha & N of Items & Keterangan \\
\hline 0,823 & 10 & Reliabel \\
\hline
\end{tabular}

Berdasarkan tabel tersebut dapat diketahui bahwa berdasarkan uji reliabilitas variabel $\mathrm{X}$ (Kualitas Pelayanan) dengan teknik Alpha Cronbach menggunakan Program SPSS, diperoleh koefisien reliabilitas sebesar 0,823 . Hal ini berarti bahwa alat ukur bersifat relibel dikarenakan koefisien reliabilitasnya mendekati 1 , sehingga relibel untuk dijadikan alat ukur penelitian ini.

4) Hasil Uji Reliability Variabel Y

\begin{tabular}{|c|c|c|}
\hline Cronbach's Alpha & N of Items & Keterangan \\
\hline 0,856 & 6 & Reliabel \\
\hline
\end{tabular}

Berdasarkan tabel tersebut dapat diketahui bahwa berdasarkan uji reliabilitas variabel $\mathrm{Y}$ (kepuasan masyarakat) dengan teknik Alpha Cronbach menggunakan Program SPSS, maka diperoleh koefisisen reliabilitas sebesar 0,856 . Hal ini berarti bahwa alat ukur bersifat reliabel dikarenakan koefisien reliabilitasnya mendekati 1 , sehingga relibel untuk dijadikan alat ukur penelitian ini.

B. Pembahasan

1) Deskripsi Variabel Kualitas Pelayanan dan Kepuasan Masyarakat.

Variabel kualitas pelayanan terdiri dari beberapa dimensi dan indikator adapun dimensi kualitas pelayanan yaitu :

$\begin{array}{ll}\text { 1) } & \text { Reliability } \\ \text { 3) } & \text { Responsiviness } \\ \text { 4) } & \text { Assurance } \\ \text { 5) } & \text { Tanphaty } \\ & \text { Tangle }\end{array}$

Untuk mengetahui dan mengukur baik tidaknya kualitas pelayanan e-ktp di Kecamatan Kramatmulya Kabupaten Kuningan, peneliti menggunakan teknik persentase sebagaimana diungkapkan Sudjana (1996:50) dengan rumus :

$$
\begin{aligned}
& p=\frac{f}{n} \times 100 \% \\
& \text { Dimana : } \\
& \mathrm{P}: \text { Persentase } \\
& \mathrm{f}: \text { frekuensi } \\
& \mathrm{n}: \text { Jumlah responden }
\end{aligned}
$$

Rekapitulasi jawaban angket variabel kualitas pelayaan (x) :

\begin{tabular}{|l|l|l|l|l|}
\hline No. & Pernyataan & $\mathbf{( \% )}$ & Kumulatif & Kriteria \\
\hline 1 & Kenyamanan Ruang Pelayanan & 67 & 100 & Cukup Baik \\
\hline 2 & Kelengkapan Fasilitas & 83 & 125 & Baik \\
\hline 3 & Akurat & 80 & 120 & Baik \\
\hline
\end{tabular}


Kebijakan: Jurnal Ilmu Administrasi

Volume 11, Nomor 1, Januari 2020

E-ISSN: 2656-2820

P-ISSN 1829-5762

\begin{tabular}{|l|l|l|l|l|}
\hline 4 & Konsisten & 81 & 121 & Baik \\
\hline 5 & Inisiatif & 77 & 115 & Baik \\
\hline 6 & Kecepatan & 79 & 118 & Baik \\
\hline 7 & Staff Berkompeten & 83 & 124 & Baik \\
\hline 8 & Ketetapan & 77 & 115 & Baik \\
\hline 9 & Kepedulian & 80 & 120 & Baik \\
\hline 10 & Pemahaman & 82 & 123 & Baik \\
\hline Jumlah & $\mathbf{1 1 8 1}$ & \\
\hline Rata-rata & $\mathbf{1 1 8 , 1}$ & \\
\hline Persentase & $\mathbf{7 8 , 9} \%$ & \\
\hline Kategori & $\mathbf{B a i k}$ & \\
\hline
\end{tabular}

Berdasarkan tabel diperoleh informasi bahwa kualitas pelayanan e-ktp Kecamatan Kramatmulya Kabupaten Kuningan berada pada kategori baik sebesar 78,9\%. Skor tertinggi berada pada indikator Kelengkapan Fasilitas (83\%) melalui pernyataan angket Fasilitas yang digunakan Kecamatan Kramatmulya sudah memadai untuk melaksanakan pelayanan e-ktp. Sedangkan skor terendah berada pada indikator kenyamanan ruang pelayanan sebesar $67 \%$ kurang luas, dan nyamannya ruangan pelayanan e-ktp menjadi salah satu faktor yang membuat masyarakat kurang puas dalam pelayanan e-ktp, dikarenakan ruangan yang sempit serta tidak tertata dengan rapih, sehingga indikator tersebut belum berjalan dengan optimal. Berdasarkan hasil pengolahan data di atas dapat diambil gambaran bahwa kualitas pelayanan e-ktp di Kecamatan Kramatmulya Kabupaten Kuningan pada umumnya sudah berjalan baik, dan perlu ditingkatkan karena masih ada indikator yang belum optimal, dan tentunya menjadi penghambat dalam menghasilkan kepuasan masyarakat yang diharapkan, oleh karena itu perlu diperhatikan dan dibenahi secara serius untuk meningkatkan kualitas pelayanan publik di Kecamatan Kramatmulya, Kabupaten Kuningan.

2) Deskripsi Variabel Kepuasan Masyarakat (y).

Variabel kualitas pelayanan terdiri dari beberapa dimensi dan indikator. Adapun dimensi Kepuasan Masyarakat yaitu :

1) Kesesuaian Harapan

2) Persepsi Kinerja

3) Penilaian Pelanggan

Untuk mengetahui dan mengukur baik tidaknya kepuasan masyarakat di Kecamatan Kramatmulya Kabupaten Kuningan, peneliti menggunakan teknik persentase sebagaimana diungkapkan Sudjana (1996:50) dengan rumus :

$p=\frac{f}{n} \times 100 \%$

Dimana :

$\mathrm{P}:$ Persentase

$\mathrm{f}$ : frekuensi

$\mathrm{n}$ : Jumlah responden

Rekapitulasi jawaban angket variabel kepuasan masyarakat (y) :

\begin{tabular}{|l|l|l|l|l|}
\hline No. & Pernyataan & (\%) & Kumulatif & Kriteria \\
\hline 1 & Pelayanan e-ktp yang diberikan sesuai harapan & 49 & 74 & $\begin{array}{l}\text { Kurang } \\
\text { Baik }\end{array}$ \\
\hline 2 & Pelayanan e-ktp yang diberikan melebihi harapan & 68 & 102 & Baik \\
\hline
\end{tabular}


Kebijakan: Jurnal Ilmu Administrasi

Volume 11, Nomor 1, Januari 2020

E-ISSN: 2656-2820

P-ISSN 1829-5762

\begin{tabular}{|l|l|l|l|l|}
\hline No. & Pernyataan & (\%) & Kumulatif & Kriteria \\
\hline 3 & Kinerja petugas pelayanan e-ktp sangat baik & 77 & 115 & Baik \\
\hline 4 & $\begin{array}{l}\text { Kinerja petugas pelayanan e-ktp lebih baik dibandingkan instansi } \\
\text { publik lainnya }\end{array}$ & 77 & 116 & Baik \\
\hline 5 & $\begin{array}{l}\text { Petugas pelayanan e-ktp memiliki pengetahuan yang luas dalam } \\
\text { memberikan informasi pelayanan }\end{array}$ & 97 & 145 & $\begin{array}{l}\text { Sangat } \\
\text { Baik }\end{array}$ \\
\hline 6 & Pelayanan e-ktp secara keseluruhan sudah baik & 79 & 119 & Baik \\
\hline Jumlah & $\mathbf{6 7 1}$ & \\
\hline Rata-rata & $\mathbf{5 7 1 , 8}$ \\
\hline Persentase & $\mathbf{7 4 . 5 \%}$ \\
\hline Kategori & Baik \\
\hline
\end{tabular}

Berdasarkan tabel tersebut dapat kita peroleh informasi bahwa kepuasan masyarakat di Kecamatan Kramatmulya Kabupaten Kuningan berada pada kategori baik sebesar $74.5 \%$. Skor tertinggi berada pada indikator penilaian pealnggan sebesar $97 \%$ melalui pernyataan angket Petugas pelayanan e-ktp memiliki pengetahuan yang luas dalam memberikan informasi pelayanan. Sedangkan skor terendah berada pada indikator kesesuaian harapan sebesar $49 \%$ melalui pernyataan angket Pelayanan e-ktp yang diberikan sesuai harapan. Berdasarkan hasil pengolahan data di atas dapat diambil gambaran bahwa kepuasan masyarakat di Kecamatan Kramatmulya Kabupaten Kuningan secara keseluruhan dapat dikatakan baik, meskipun ada beberapa indikator yang perlu diperhatikan dan ditingkatkan misalnya mengenai kesesuaian harapan yang diminta masyarakat, sehingga diharapkan kepuasan masyarakat di Kecamatan Kramatmulya Kabupaten Kuningan dapat meningkat dengan optimal.

3) Analisis Pengaruh Kualitas Pelayanan E-KTP Terhadap Kepuasan Masyarakat.

Hipotesis penelitian adalah kualitas pelayanan e-ktp memiliki pengaruh positif/ signifikan dalam meningkatkan kepuasan masyarakat Kecamatan Kramatmulya Kabupaten Kuningan. Berikut hasil penghitungan SPSS yang tersaji pada tabel di bawah ini :

Tabel Korelasi Kualitas Pelayanan denganKepuasan Masyarakat :

Model Summary

\begin{tabular}{|l|l|l|l|l|}
\hline Model & $R$ & R Square & Adjusted R Square & Std. Error of the Estimate \\
\hline 1 & $.840^{\mathrm{a}}$ & .706 & .696 & 1.36250 \\
\hline
\end{tabular}

a. Predictors: (Constant), $\mathrm{X}$

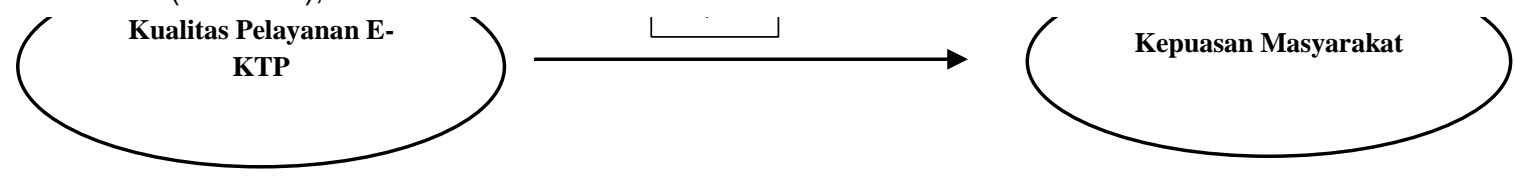

Dari tabel di atas dapat diketahui bahwa ada korelasi antara kualitas pelayanan dengan kepuasan masyarakat. Adapun besar koefisien korelasi tersebut adalah 0,840 (R). Angka R di dapat 0,840, artinya korelasi antara variabel kualitas pelayanan dengan kepuasan masyarakat terjadi hubungan yang sangat erat karena nilai koefisien korelasi mendekati angka 1. Dari angka tersebut 


\section{Kebijakan: Jurnal Ilmu Administrasi \\ Volume 11, Nomor 1, Januari 2020 \\ E-ISSN: 2656-2820 \\ P-ISSN 1829-5762}

sekaligus menjawab hipotesis mengenai kualitas pelayanan memiliki pengaruh positif/ signifikan dalam meningkatkan kepuasan masyarakat Kecamatan Kramatmulya, Kabupaten Kuningan. Adapun besaran sumbangan pengaruh variabel kualitas pelayanan e-ktp terhadap kepuasan masyarakat ditunjukkan dalam tabel di atas sebesar 0,706 ( $\mathrm{R}$ Square). Angka ini menunjukan koefisien determinasi yang diubah ke dalam bentuk presentase yang artinya sumbangan pengaruh variabel kualitas pelayanan terhadap kepuasan masyarakat sebesar 70,6\%. Sisanya yakni sebesar 29,4\% merupakan sumbangan variabel lain yang mempengaruhi kepuasan masyarakat yang tidak diteliti dalam penelitian ini. Adapun gambaran hasil penelitian mengenai kualitas pelayanan publik tersaji dalam gambar di bawah ini.

Gambar Model Penelitian :

Berdasarkan gambar tersebut dapat diketahui bahwa pengaruh variabel kualitas pelayanan e-ktp terhadap kepuasan masyarakat sebesar 70,6 \%, sedangkan pengaruh variabel lain sebesar 29,4\%. Artinya, hipotesis yang peneliti ajukan terbukti dan dapat diterima bahwa kualitas pelayanan e-ktp memiliki pengaruh signifikan/positif terhadap kepuasan masyarakat di Kecamatan Kramatmulya, Kabupaten Kuningan.

\section{KESIMPULAN}

Berdasarkan penelitian yang dilakukan, maka dapat ditarik kesimpulan sebagai berikut: Pengaruh kualitas pelayanan e-ktp di Kecamatan Kramatmulya Kabupaten Kuningan yang diukur melalui dimensi pelayanan yakni Bukti Langsung (Tangibles), Kehandalan (Reliability), Daya Tanggap (Responsiveness), Jaminan (Assurance), Empati (Emphaty) sebesar 70,6 \% (tujuh puluh koma enam persen), hal ini membuktikan bahwa kualitas pelayanan e-ktp mempunyai pengaruh terhadap kepuasan masyarakat. Sedangkan sisanya yakni $29,4 \%$ (dua puluh sembilan koma empat persen) merupakan hal-hal lain yang berpengaruh terhadap peningkatan.

\section{DAFTAR PUSTAKA}

Buku:

Fathoni, A. 2006. Metodologi, Penelitian, dan Penyusunan Skripsi. Jakarta: PT. Rhieka Cipta

Hardiansyah .2011. Kualitas Pelayanan Publik (Konsep, Dimensi, Indikator dan Implementasinya). Yogyakarta: Gava Media.

Hasibuan, M.2002. Manajemen Sumber Daya Manusia. Jakarta: Bumi Aksara.

Pasolong, Harbani. 2007. Teori Administrasi Publik. Bandung: Alfabeta.

Satibi, Iwan. Manajemen Publik Dalam Perspektif Teoritik dan Empirik. 2012. Bandung: Unpas Press

Satibi, Iwan. Teknik Penulisan Skripsi, Tesis, dan Disertasi. Bandung: CEPLAS (Centre For Political and Local Autonomy Studies).

Siagian, Sondang P. Filsafat Administrasi. 2014. Jakarta : Bumi Aksara

Sugiyono. 2016. Metode Penelitian Kuantitatif, Kualitatif, dan R\&D. Bandung: Alfabeta.

Priansa, Donni Junni. 2018. Manajemen Organisasi Publik. Bandung: Pustaka Setia

Dokumen:

Undang-undang No. 25 Tahun 2009 Tentang Pelayanan Publik

Keputusan Mentri Pendayagunaan Aparatur Negara (Meneg PAN) Nomor 63/KEP/M.PAN/7/2003

LPPD Kecamatan Kramatmulya Kabupaten Kuningan 